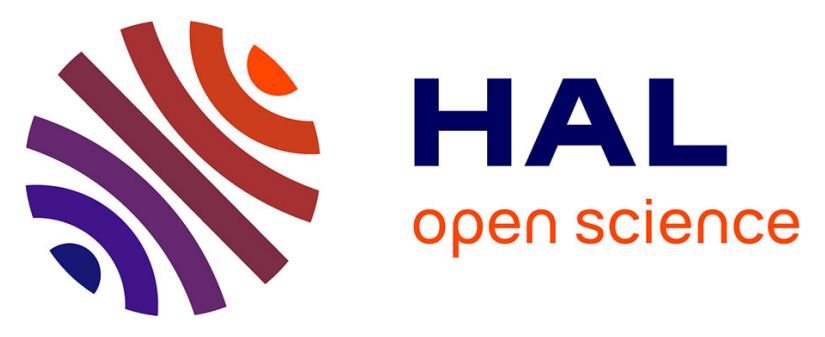

\title{
Do short food supply chains go hand in hand with environment-friendly practices? An analysis of French farms
}

Magali Aubert, Geoffroy Enjolras

\section{- To cite this version:}

Magali Aubert, Geoffroy Enjolras. Do short food supply chains go hand in hand with environmentfriendly practices? An analysis of French farms. 8. Journées de recherches en sciences sociales (JRSS), Institut National de Recherche Agronomique (INRA). UMR Economie Appliquée de Grenoble (1215).; Société Française d'Economie Rurale (SFER). FRA.; Centre de Coopération Internationale en Recherche Agronomique pour le Développement (CIRAD). FRA., Dec 2014, Grenoble, France. 26 p. hal-02742710

\author{
HAL Id: hal-02742710 \\ https://hal.inrae.fr/hal-02742710
}

Submitted on 3 Jun 2020

HAL is a multi-disciplinary open access archive for the deposit and dissemination of scientific research documents, whether they are published or not. The documents may come from teaching and research institutions in France or abroad, or from public or private research centers.
L'archive ouverte pluridisciplinaire HAL, est destinée au dépôt et à la diffusion de documents scientifiques de niveau recherche, publiés ou non, émanant des établissements d'enseignement et de recherche français ou étrangers, des laboratoires publics ou privés. 


\title{
Do short food supply chains go hand in hand with environment-friendly practices?
}

\author{
An analysis of French farms
}

\author{
Magali Aubert*, Geoffroy Enjolras ** \\ * UMR 1110 MOISA, INRA-Montpellier Supagro \\ 2 place Viala, 34060 Montpellier Cedex 2, France \\ aubert@ supagro.inra.fr \\ ** Univ. Grenoble Alpes, UMR 5820 CERAG, IAE \\ Domaine universitaire, B.P. 47, 38040 Grenoble Cedex 9, France \\ geoffroy.enjolras @ iae-grenoble.fr
}




\begin{abstract}
This article deals with the presumed relationship between environment-friendly practices, such as organic farming, and the adoption of short food supply chains at farm level. These two patterns of production and distribution appear to be linked because they meet the consumers' expectations in terms of quality and proximity. Calling on the literature, we formulate testable hypotheses regarding the combined adoption of organic farming and short food supply chains by farmers. An econometric model with simultaneous equations allows the close link between the environmental quality of production and vertical integration to be measured. The data are drawn from the 2010 census of French farms which provides a full overview of strategies implemented by producers regarding their specialization. Particular attention is paid to two complementary farm specializations (wine-growing and arboriculture) which correspond to farms most concerned by organic farming. The results show that when a farmer practises organic farming, the farm becomes integrated and conversely when a farm is integrated, the farmer is likely to adopt organic farming. This complementarity of producers' choices offers certain perspectives for the improvement of short food supply chains while considering environment-friendly practices.
\end{abstract}

Keywords: organic farming, short food supply chains, FADN, France

JEL codes: Q12, Q14, Q15

Acknowledgments: This article benefited from the financial support of the French National Research Agency (Project ANR-11-ALID-0006ILLIAD). 


\section{Introduction}

The quality of agricultural production is a key concern for both producers and consumers. Since the early 1980s, an environmental awareness has emerged in response to intensive farming practices, such as the use of chemical inputs (Heckman, 2006). This renewed interest is characterized by the emergence and development of alternative food networks (AFNs). AFNs differ from traditional production and distribution channels while claiming to meet both producers' and consumers' requirements (Venn et al., 2006). Their development has been encouraged at the European level through the second pillar of the Common Agricultural Policy (Goodman et al., 2012) and at national level in France by the Ministry of Agriculture as part of the agricultural modernization policy.

There is a broad range of AFNs encompassing both organic farming (OF) and short food supply chains (Venn et al., 2006). Each of these forms of AFN aims at providing responses to limitations encountered within the conventional food sector. For instance, organic farming offers a means of restoring consumer confidence that was shaken by food scandals, leading to the development of new quality standards by both the public authorities and the private sector (Giraud-Héraud et al., 2006). These standards ensure consumers that production complies with environment constraints (Tuomisto et al., 2012).

At the same time, the development of short food supply chains (SFSCs) has been encouraged because they are characterized by a relation of proximity, with no more than one intermediary involved in the exchange between the producer and the consumer (Renting et al., 2003). Moreover, such distribution channels go hand in hand with rural development (Kneafsey et $a l ., 2013)$. SFSCs characterize the active involvement of farmers in the food market beyond production. In economic terms, thanks to the absence of intermediaries, producers capture more of the added value generated by their production (Broderick et al., 2011; Aubert and Enjolras, 2013) while consumers benefit from lower prices compared to purchases made through a long supply chain. Beyond the economic gains provided by SFSCs, consumers expect a higher level of quality in this kind of production. The current trend translates into greater value placed on production sold directly to the consumer who is expecting a higher level quality and greater proximity in return.

The evolution of both quality requirements and marketing channels does not seem to be unrelated (Ilbery et al., 2005; Kottila and Rönni, 2008). However, these two topics have mainly been studied separately in the literature: SFSCs are examined using the Transaction Cost theory (Grote and Grote, 2009; Burton et al., 2003; McNamara et al., 1991) while commitment to environmental quality (organic farming) is considered through the ResourceBased View theory (Sylvander and Schieb-Bienfait, 2006; Moustier and Thi Tan Loc, 2013). Few studies consider both the link between SFSCs and environment-friendly practices, instead focussing primarily on regional case studies in Austria (Penker, 2006), England (Ilbery and Maye, 2005) and France (Maréchal and Spanu, 2010). Even if Maréchal and Spanu (2010) mention a possible bilateral causality, all these studies consider only the unilateral causality which considers that SFSCs lead to more ecological practices.

Consequently, this study seeks to appreciate the joint determinants of these strategies, which concern both producers and consumers. More precisely, our goal is to measure the effective simultaneity of these two choices that can explain the recent evolutions in favour of SFSCs and OF. The in-depth analysis relies on the latest French agricultural census conducted in 2010, which provides an exhaustive view of French agriculture with all farms being surveyed. 
Within this census, we focus on farms specializing in permanent crops since these farms are most prominently involved in short food supply chains (Kneafsey et al., 2013). More precisely, we differentiate wine-growing from arboriculture because of their specificities: wine-growing is a perennial production while this is not the case for arboriculture.

Our article is structured as follows. In the first section, we develop the theoretical framework of our analysis while in the second section we present the analytical framework. In the third section, we present a descriptive analysis and the results of the econometric model before concluding.

\section{Theoretical and analytical framework}

Our analysis relies on the principle that producers make simultaneous choices in terms of vertical integration (adoption of SFSCs) and the implementation of environment-friendly production practices (adoption of OF). Because few studies have been conducted on this subject, it appears necessary to consider the factors identified in the literature which can influence, either separately or together, the adoption of vertical integration and production practices.

In order to overcome this limitation and mirroring the existing literature, we assume that production practices are more dependent on farm and farmers' characteristics while vertical integration depends more on transaction characteristics and the need to reduce uncertainty. We therefore explain the quality implemented by farmers using the Resource-Based View theory while calling on the Transaction Cost theory to understand vertical integration.

\subsection{Determinants of environment-friendly practices}

The adoption of environment-friendly agricultural practices has been widely studied in the literature using the Resource-Based View (Penrose, 1959). The most relevant determinants of the decision to adopt this type of practice are therefore clearly identified even if their impact on adoption may vary from one study to another.

Irrespective of the context or production considered, the literature unanimously highlights the importance of taking available resources into account. All studies converge towards a positive impact between the size of the farm and the implementation of environment-friendly practices (Dörr and Grote, 2009; Burton et al., 2003; McNamara et al., 1991; Aubert et al., 2013; Aubert and Enjolras, 2013).

Independent of the physical size of the farm, the relative importance of workers in the adoption of environmental-friendly practices is widely highlighted (Galt, 2008; Aubert and Enjolras, 2013). Workers can come from the farmer's family or be external employees. All workers have to be considered because the weight of family workers is relatively more important on small farms.

Another element that is supposed to influence practices implemented by producers is the degree of specialization of the farm. The degree of specialization is measured by the share of the revenue that depends on the main crop. The more a farm is specialized, the more it is likely to implement practices that are environment-friendly (Dörr and Grote, 2009; Aubert et al., 2013). 
$H_{1}$ : The more resources available, the more the farm is likely to implement environment-friendly practices

Beyond available resources, the Resources-Based View theory highlights the importance of skills. With regard to the farmer's characteristics, almost all studies dealing with SFSCs highlight the importance of the farmer's level of education and his age. The level of education can be considered in two ways, the first being the general level of education and the second being the agricultural level of education. The general result is that more educated farmers are more likely to implement such practices (McNamara et al., 1991; Fernandez-Cornejo and Ferraioli, 1999; Dörr and Grote, 2009; Aubert et al., 2013; Aubert and Enjolras, 2013). Additionally, it appears that more experienced farmers, i.e. older ones, are less likely to adopt environment-friendly practices (Fernandez-Cornejo, 1996, Dörr and Grote, 2009; Aubert et al., 2013).

\section{$\mathrm{H}_{2}:$ The more skills available, the more the farm is likely to implement environment- friendly practices}

Moreover, we consider the eventuality that the farmer has another activity and thus another source of income. In that case, farmers may be less likely to implement environment-friendly practices due to a lack of available time (McNamara et al., 1991; Fernandez et al., 1994; Fernandez-Cornejo, 1996; Aubert and Enjolras, 2013; Aubert et al., 2013). Indeed, such practices translate into more time spent on farms to observe the production.

In addition to the resources and skills available on farms, the commercial strategy is highlighted as having an impact on the implementation of environmental-friendly practices (Venn et al., 2006). Selling through SFSCs helps reduce quality uncertainty. Environmental attributes are difficult to measure for consumers, thus making them non-observable. Hence, this commercial strategy limits product quality uncertainty (Prigent-Simonin and HéraultFournier, 2005; Moustier and Thi Tan Loc, 20013) and reduces the need to indicate product quality using labels.

\section{$\mathrm{H}_{3}$ : Farms selling through short supply chains are less likely to implement environment-friendly practices}

\subsection{Determinants of vertical integration}

Vertical integration involves integrating different stages of a single process. These stages can be either productive or commercial. The Transaction Costs theory (TCT) underlines the fact that vertical integration depends on frequency, uncertainty and specificity of assets (Williamson, 1987). Because our study is conducted at farm level and the TCT is by nature available at transaction level, we adopt the hypothesis that uncertainty and specificity of assets are the same for all transactions at farm level, since frequency cannot be defined at farm level.

The aim of this analysis is to understand why farmers choose to sell their production themselves instead of selling it through intermediaries. This vertical integrated strategy means that the farmer is willing to perform an additional commercial activity which is very different from production. The farmer is then responsible for all stages of the supply chain from 
production to selling, which means that only large farms are able to become integrated (Moustier and Thi Tan Loc, 2013).

\section{$\mathrm{H}_{4}:$ The size of the farm is positively linked to the degree of integration}

We assume that the degree of uncertainty has a positive impact on the strategy of selling directly to the consumer. The more a farm faces uncertainty, the less its income is subject to uncertainty and the greater its degree of vertical integration. To assess uncertainty, we assume that this parameter is constant within a given farm and reflects only the uncertain environment of the farm. Because this uncertainty is difficult to measure, several indicators capable of reducing it can be considered.

The first indicator is the degree of specialization. More precisely, we can differentiate intraand inter-diversification. For instance, a farm may specialize in wine-growing and, within this specialization, cultivate different types of grape, a practice referred to as intra-diversification. The same farm could also cultivate additional crops such as fruits, which is called interdiversification. Computing inter-diversification relies on the indicator defined by Aubert (2013), which is a counter of all types of productions based on the specialization items. A specialized farm is generally exposed to higher crop income volatility (Purdy et al., 1997; Enjolras et al., 2014). Because of the increase in volatility, the uncertainty faced by the farmer is higher and is reflected in a higher degree of integration.

Conversely, subscribing to multi-peril crop insurance or contributing to a mutual fund reduces the uncertainty associated with crop yields (Enjolras and Sentis, 2011). Their adoption may reduce the financial uncertainty of the farm and lead to less vertical integration.

\section{$H_{5}:$ The more the farm faces uncertainty, the more it is likely to be vertically integrated}

Echoing, Moustier and Thi Tan Loc (2013), we consider the specificity of assets through the implementation of environment-friendly practices, e.g. the adoption of the "organic farming" label. Labelled farms should respect precise specifications aimed at reducing asymmetric information effects regarding product quality (Akerlof, 1970). Producers involved in SFSCs are "building trust" when they adopt labels (Vincq et al., 2010). This point explains why integrated farms are more often boast the "organic farming" label than others (Aubert, 2013; Redlingshofer, 2008).

\section{$H_{6}:$ The more assets are specific, the more the farm is integrated}

These research hypotheses are tested within the empirical framework presented hereafter. 


\section{Empirical framework}

\subsection{Dataset}

To take the individual and structural characteristics of the farms and the strategies adopted by farmers into account simultaneously, we use data from the exhaustive census of French farms (tables 1a and 1b). By doing so, we can evaluate the determinants of both the implementation of organic farming and the adoption of an integrated marketing channel.

The survey was conducted in 2010 and includes 514,186 farms encompassing all agricultural sectors, sizes and specializations ${ }^{1}$, regardless of their production, location and legal status. The richness of this database allows us to assess the strategies adopted by producers correctly.

Our study focuses on farms specializing in wine-growing and arboriculture because they are relatively more likely to sell their produce directly to consumers (Aubert, 2013). The database accounts for 60,174 and 11,714 farms respectively.

\section{Table 1a. List of main variables - Determinants of environment-friendly practices}

\section{Table 1b. List of main variables - Determinants of vertical integration}

Because our study focuses both on environmental quality and the distribution channels adopted by producers, we present a definition of these concepts below.

\subsection{Environment-friendly practices}

In this paper we focus specifically on environmental quality, which can be measured both through the quality declared to consumers and through the quality implemented in practice by producers. One contribution of our study is to put these two measures into perspective in order to validate their consistency. Barzel (1982) highlights the fact that the difficulty farmers face when communicating about quality leads to increased integration. The use of labels provides an answer to this concern (Darby and Karni, 1973). Some of them are reliable as they are validated by a third party while others are commercial and provide a relatively stable quality (Gonzalez et al., 2007). These two kinds of label refer to different ways of signalling and enforcing quality. Since our database lets us assess both of them, comparing their consistency is a way to confirm that the quality declared to consumers corresponds to the quality implemented by producers.

One of the most acknowledged quality signs is "organic farming" (OF) which is assumed to be associated with environment-friendly practices. The data at our disposal identify farmers who have adopted the OF label, considering both farmers who are currently committed to OF and farmers who plan to adopt it within 5 years. We aggregate these two configurations because we assume that the adoption of such a label is based on stable characteristics over a long period.

The salient question is to verify in practice whether OF is effectively associated with effective protection of the environment. Several indicators can be used to ensure farms comply with quality standards. Both Galt (2008) and Aubert and Enjolras (2013) underlined the

\footnotetext{
${ }^{1}$ Farms specialize in a produce when $2 / 3$ of their standard gross output is derived from this production.
} 
importance of using a recent sprayer to reduce the quantity of chemical inputs used. Furthermore, Fernandez-Cornejo (1996) and Galt (2008) insisted on the importance of performing an internal control of treatments applied to plots. Following this rationale, we first take account of the age of the sprayer and whether or not it is controlled. We then differentiate farms depending on whether they perform an internal control or if they delegate this control to a third party. We also consider the share of farmed area which is not treated using phytosanitary products.

We can therefore examine the relationship between declared and effective quality by comparing the OF label to the efforts effectively made by producers to implement environmentally-sound practices. For each economic and technical orientation (ETO), we computed Chi2 and correlation tests according to the nature of the variable considered. The results globally confirm that OF is more likely to be associated with environment-friendly practices (Table 2).

\section{Table 2. Correspondence between quality declared to consumers and quality implemented in practice by producers}

Organic farmers use more recent sprayers, which are on average 8.6 years old while sprayers used by other farmers are on average 10 years old. Moreover, organic farmers do not to perform phytosanitary treatments on $16.59 \%$ of their cultivated area while this percentage represents less than $11.13 \%$ for other farmers. The link identified between observed quality and implemented quality is also confirmed with regard to sprayer controls as they are performed by $33.26 \%$ of organic farmers and $28.95 \%$ of other farmers. Among these, we observe that $91.64 \%$ and $80.28 \%$ of organic farmers and other farmers respectively call on external control.

All these elements highlight the fact that quality declared to consumers goes hand in hand with practices effectively implemented by producers. Consequently, OF appears to be a good indicator of quality declared to consumers.

\subsection{Vertical integration}

Vertical integration cannot be simply defined as it refers to a multitude of cases. Thanks the database, we are able to assess the three degrees of integration that are usually considered: the integrated, hybrid and non-integrated forms (Williamson, 1987).

By definition, farms that are not vertically integrated do not perform any integrated transaction. These producers, who have no contact with their consumers, can therefore be easily identified in the database. Indeed, these farms declare that their turnover does not depend on SFSCs.

Once non-integrated farms are identified, differentiating integrated farms means the distribution channel must be considered. Echoing Moustier (2013), short supply chains can be a means of detecting integration. We adopt the hypothesis that selling all or part of production through SFSCs differentiates non-integrated farms from other farms. More precisely, we consider both direct and indirect selling to be short channels ${ }^{2}$. In this context, distinguishing

\footnotetext{
${ }^{2}$ The French Ministry of Agriculture defines indirect selling as a situation in which there is no more than one intermediary between the producer and the consumer.
} 
hybrid and integrated forms requires the economic impact of short channels on farm income to be considered. Farms will be qualified as integrated if they sell a part of their production corresponding at least to $50 \%$ of their turnover through short channels. In that case, we assume that almost all transactions are conducted in short channels between the producer and the consumer. Hybrid forms then correspond to farms that sell part of their production via short channels but whose turnover does not depend primarily on this activity.

\subsection{The model: simultaneous equations}

Our study focuses both on environment-friendly practices and vertical integration of the supply chain. Because these two behaviours are long-term management strategies within alternative food networks, they are assumed to be chosen simultaneously. Therefore, farmers who adopt the OF label are more likely to sell their production through a short circuit and conversely, farmers who sell their production through this channel are more likely to adopt such a label. This means that the way farmers implement quality has an impact on the integration of the supply chain and vice versa.

This model can be estimated thanks to the size of our sample. We can then go beyond existing studies (Penker, 2006; Ilbery and Maye, 2005; Maréchal and Spanu, 2010) in which the analyses faced a lack of data.

Figure 1. Adoption of the OF label and vertical integration by farms
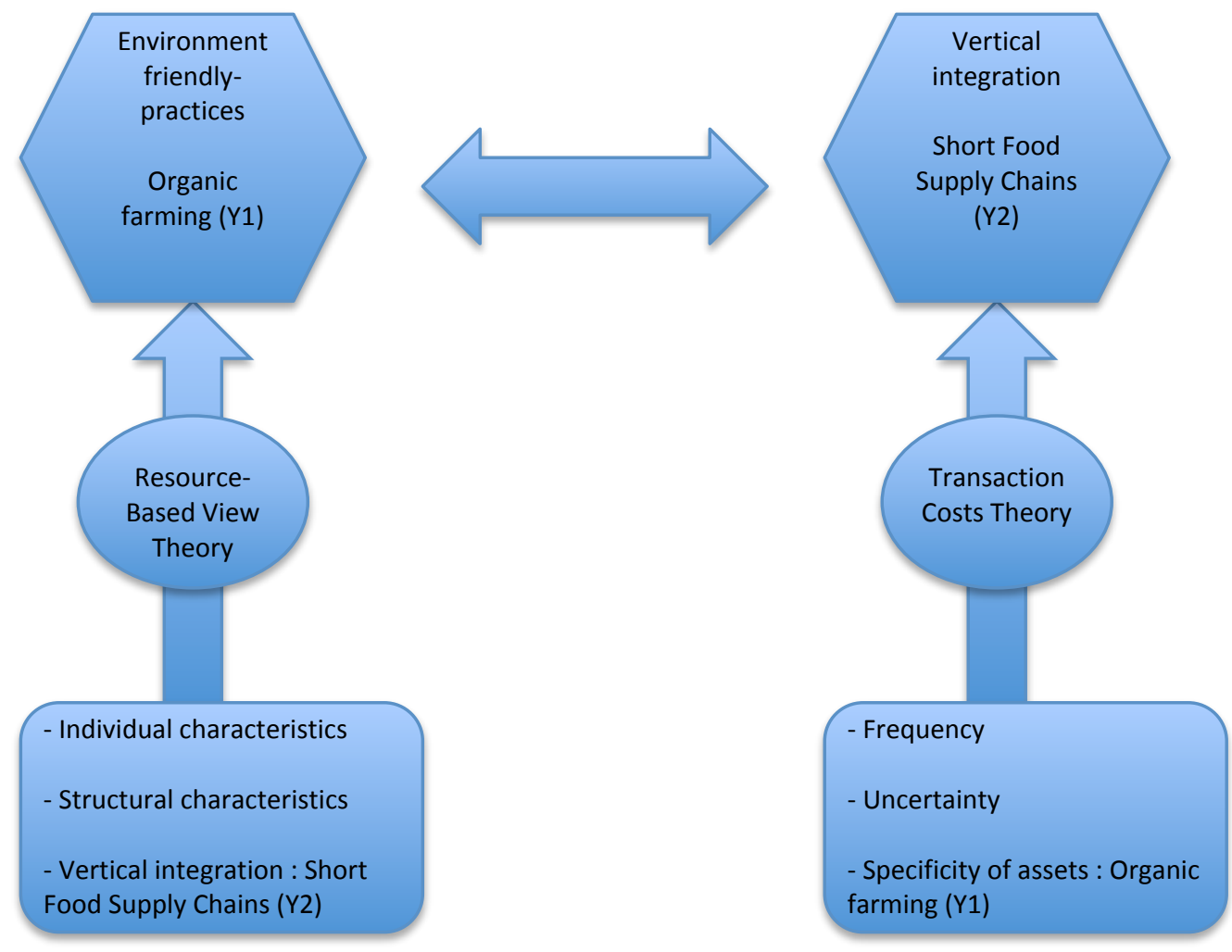
Given the joint adoption of environment-friendly practices and vertical integration, we estimate an econometric model based on simultaneous equations. Because of the possible feedback effect, considering each equation independently would ignore the fact that farmers who sell through SFSCs may be more likely to adopt the OF label and conversely, farmers who adopt this label may be more likely to sell through SFSCs.

Maréchal and Spanu (2010) showed that different kinds of relationship exist between the adoption of the OF label and selling through SFSCs. While some farmers first adopt the label before selling through short channels, others decide to go the opposite way while others adopt both strategies simultaneously. Based on a survey of farmers, our model examines the possible simultaneity of these two strategies considering that each strategy can have an impact on the other. Such a consideration is translated into the equations given below:

\section{Organic Farming}

$$
\begin{aligned}
=\beta_{0}+\beta_{1} \times \text { Structural Characteristics }+ & \beta_{2} \times \text { Individual Characteristics } \\
& +\beta_{3} \times \text { Vertical integration }+\varepsilon
\end{aligned}
$$

Vertical integration $=\gamma_{0}+\gamma_{1} \times$ Size $+\gamma_{2} \times$ Uncertainty $+\gamma_{3} \times$ Organic Farming $+\mu$

Where $\beta_{0}$ and $\gamma_{0}$ represent the constant of the first and second models respectively; $\beta_{1}, \beta_{2}, \beta_{3}$ are the coefficients associated with each group of variables that explain the adoption of the organic farming label; $\gamma_{1}, \gamma_{2}, \gamma_{3}$ are the coefficients associated with each group of variables that explain vertical integration; $\varepsilon$ and $\mu$ are the residues of the first and second models respectively.

As our database corresponds to a census conducted for a given year, we are able to observe these two strategies but not to identify the date of their implementation. Because these strategies are conducted in the long run, we assume that an "organic farming" label is adopted at the same time as the decision to implement environment-friendly practices. A panel approach might have provided more information about the nature of the causality: one-way versus mutual causality.

These strategies are defined using qualitative variables. While the adoption of "organic farming" can only be a dichotomous variable, vertical integration should be a quantitative variable. With the data at our disposal, we are only able to measure this integration by an ordered variable from no-integration to integration. Such definition corroborates the definition usually adopted by the Transaction Costs theory differentiating integrated, non-integrated and hybrid forms (Williamson, 1971).

Considering a model with simultaneous equations, we assume that the adoption of the farmer's strategies depends on unobserved quantitative variables. For instance, the farmer chooses to adopt the "organic farming" label if he considers that this practice will provide him with increased utility. For this strategy, the unobserved quantitative model and the observed qualitative model described below are as follows:

$$
\begin{gathered}
Y^{*}=X^{\prime} \beta+\varrho \\
Y=1 \text { if } Y^{*}>0 ; 0 \text { otherwise }
\end{gathered}
$$


Where $\beta$ is the vector of coefficient associated with factors affecting the latent variable and thus the dichotomous choice observed; $\varrho$ is the error term of the equation

The relevance of the simultaneous model is validated since the correlation of the error terms is significantly different from 0 (Berndt, 1991).

\section{Results}

In this section, we present the results of summary statistics, complemented by econometric modelling based on simultaneous equations.

\subsection{Summary statistics}

The adoption of organic farming (OF) differs according to the specialization considered. The label has been adopted by $8.78 \%$ of farms specializing in wine-growing and $13.02 \%$ of farms specializing in arboriculture. Because of this difference, we consider each of these specializations separately.

Farmers who have adopted the OF label are younger and more educated both in terms of agricultural and general education (tables $3 \mathrm{a}$ and $3 \mathrm{~b}$ ). Otherwise, they claim to work more on their farms: more than $75 \%$ of organic farmers spend more than $3 / 4$ of their work time on their farm while this percentage is less than $60 \%$ for other farmers. These results appear to be independent of farm specialization.

Table 3a. Individual characteristics of farmers specializing in wine-growing Table $3 b$. Individual characteristics of farmers specializing in arboriculture

Organic farmers also present similar specificities independent of their specialization (tables $4 \mathrm{a}$ and $4 \mathrm{~b}$ ). A salient result is that OF farms correspond to larger farms on which labour is less intensive. In addition, we observe that the labour force is more predominantly made up of employees rather than family members, and more precisely by permanent employees.

Farms specializing in wine-growing which adopt OF present a higher degree of diversification both in terms of intra- and inter-diversification. OF therefore goes hand in hand with a need to provide a more diversified production and to offer a larger wine production range. Farms specializing in arboriculture do not exhibit such similarities.

\section{Table 4a. Structural characteristics of farms specializing in wine-growing Table $4 b$. Structural characteristics of farms specializing in arboriculture}

Considering integration leads to a substantial differentiation between specializations. While organic farmers specializing in wine-growing are more likely to be integrated, those specializing in arboriculture are more likely to correspond to the hybrid form. Irrespective of their specialization, all organic farmers considered are less likely to be non-integrated (tables $5 \mathrm{a}$ and $5 \mathrm{~b})$.

Table 5a. Adoption of the OF label and integration on farms specializing in winegrowing

Table 5b. Adoption of the OF label and integration on farms specializing in arboriculture 
When considering the determinants of integration, we observe that there are several differences between specializations (tables $6 \mathrm{a}$ and $6 \mathrm{~b}$ ). Integrated farms specializing in winegrowing are larger than hybrid and non-integrated concerns, while integrated farms specializing in arboriculture are the smallest. Similarly, while the former are less specialized in their dominant crop, the opposite is true for the latter. Nevertheless, a common element to both specializations is their degree of diversification: integrated farms are clearly more diversified than other ones.

In the wine-growing sector, crop insurance and mutual funds are not adopted at all by integrated farmers. The reason may be the cost of the inefficiency of these products in this configuration. The less a wine-grower is integrated, the more he selects financial risk management instruments. The trend is similar for farms specializing in arboriculture, even if integrated farmers are more interested in risk management tools.

Table 6a. Characteristics of farms specializing in wine-growing according to their degree of integration

Table 6 b. Characteristics of farms specializing in arboriculture according to their degree of integration

\subsection{Econometric models}

The results of the econometric models are provided in table 7.

\section{Table 7. Econometric models}

We must first mention the relevance of considering a model with simultaneous equations instead of separate estimations for each strategy: indeed, we observe a correlation between error terms. We can then confirm that there is mutual causality between strategies adopted by farmers: farmers who adopt organic farming are more likely to be integrated and conversely, farmers whose farm is integrated are more likely to adopt environment-friendly practices.

\subsubsection{Determinants of environment-friendly practices}

The results highlight that, in accordance with the literature, resources and skills as well as the degree of integration have a positive influence on the adoption of organic farming.

We confirm the importance of labour as a strategic resource for implementing environmentfriendly practices. Farms that adopt the organic farming (OF) label have fewer salaried employees per hectare but these employees are more permanent, which indicates extensive production. When fulfilling the OF label requirements, farmers must design their agricultural practices by paying more attention to the monitoring of the production, which cannot be done by "mechanical" means but with more permanent employees.

We also observe that the more a farm is diversified in its wine-growing production, the more it is likely to adopt organic farming while the opposite effect is observed for arboriculture. Moreover, for farms specializing in wine-growing production, the more the standard gross margin depends on this specific activity, the more the farmer is likely to adopt the "organic farming" label. 
The smallest farms are more likely to adopt organic farming when their economic and technical orientation (ETO) is wine-growing while the opposite is true for farms whose ETO is arboriculture. These two results point to structural differences between these two sectors, the former being less extensive than the latter. $\mathrm{H}_{1}$ is therefore partially validated.

Focusing on individual characteristics, organic farming is adopted by farmers who are more educated, younger and more present on their farm than other farmers. This result, which confirms $\mathrm{H}_{2}$, is in line with the need for careful monitoring of production which cannot use traditional production patterns such as the application of phytosanitary products.

Whatever the ETO, vertical integration appears to be an essential element in differentiating farms regarding the adoption of organic farming. The more the farm is integrated, selling through short supply chains, the more it is likely to implement environment-friendly practices, which validates $\mathrm{H}_{3}$. By doing so, the farm seeks to enhance the quality and the value-added of its production which can be considered a specific asset.

\subsubsection{Determinants of vertical integration}

Based on the Transaction Costs theory, three main hypotheses have been formulated regarding the determinants of vertical integration.

The results confirm that the size of the farm is strongly linked to the degree of integration, even if we observe a sectorial effect. The most integrated farms whose ETO is wine-growing correspond to the biggest ones, while the contrary applies to farms whose ETO is arboriculture. $\mathrm{H}_{4}$ is thus partially validated. This result may be in line with the fact that the former perform more regular transactions (grapes and above all bottles) compared to the latter whose production is more seasonal.

Considering uncertainty and its supposed positive impact on vertical integration, we observe differentiated behaviour between farmers according to their main production. The more winegrowing farms are diversified and insured, the less likely they are to sell their production through short channels, which validates $\mathrm{H}_{5}$. This result is the opposite for arboriculture. In this sector, farms that sell through short supply chains are probably willing to meet consumer requirements in terms of product diversity because they offer consumers a wider variety of products.

Finally, we notice a very strong and positive link between the practice of organic farming and vertical integration, which validates $\mathrm{H}_{6}$. Because they comply with strong environmental constraints, farmers involved in organic farms are encouraged to sell their produce themselves using short supply chains. They can then benefit directly from a high quality image.

\section{Conclusion}

In recent years, consumers have been looking for more quality produce. This expectation has been satisfied by producers through changes in production processes and the development of short food supply chains. Selling using short channels can be seen as an alternative to other more traditional channels.

Conceptually speaking, improving the quality of produce through environment-friendly practices and integrated supply chains appear to be closely linked. This is particularly true 
when considering the growth of organic farming which requires the adoption of and compliance with technical specifications. These increasing requirements are important issues for producers and adaptation depends on both individual and structural characteristics. Nevertheless, the choice to sell through short food supply chains refers to the conditions of the transactions.

The census of French farms performed in 2010 provided a comprehensive overview of strategies implemented by producers with regard to their specialization. Since farms specializing in wine-growing and arboriculture are more concerned with the adoption of organic farming and short food supply chains, we focused our study on these farms.

Using an econometric model with simultaneous equations, we were able to demonstrate that farmers who adopt organic farming label are more likely to sell their produce through short food supply chains. Conversely, farmers who sell their production using this channel are more likely to implement environment-friendly practices. Such results highlight the fact that proximity can be associated with quality, irrespective of the production considered. Moreover, our study confirms that environment-friendly practices are more likely to be implemented by younger producers who are furthermore better educated and claim to work more on their farm. Such practices require increased labour. Despite some differences depending on farm specialization, these results and their interdependency tend to prove that the quality of agricultural products and processes can be enhanced in several ways, either through the commercial channel or the adoption of environmental labels.

Two limitations on our study can be identified. The first is the lack of historical data to assess the stability of choices observed for producers. The second is that our study focuses only on permanent crops. A future work would be to conduct a similar study on other kinds of production. The objective would be to test the link between the quality of production and the vertical integration of supply chains, thus extending the scope of our results to non-perennial plants.

\section{References}

Akerlof, G.A. (1970), "The market of "lemons": quality uncertainty and the market mechanism", Quarterly Journal of economics, LXXXIV: 488-500.

Aubert, M. (2013), "Déterminants de la commercialization en circuit court: Quelles exploitations, sur quelles exploitations ?", INRA-SFER-CIRAD, Angers-France, December 2013, 15p.

Aubert, M. and Enjolras, G. (2013), "Quelles incitations pour la vente au détail ? Une analyse économique et financière des exploitations agricoles françaises", INRA-SFER-CIRAD, Angers-France, December 2013, 21p.

Aubert, M., Codron, J.-M., Rousset, S., and Yercan, M. (2013), "The adoption of IPM practices by small scale producers: the case of greenhouse tomato growers in Turkey", INRASFER-CIRAD, Angers-France, December 2013, 26p.

Barzel, Y. (1982), "Measurement cost and the organization of markets", Journal of Law and Economics, XXV: 27-50. 
Berndt, E.R. (1991), "The practice of econometrics classic and contemporary", Addison Wesley, 702p.

Broderick, S., Wright, V., and Kristiansen, P. (2011), "Cross-Case Analysis of ProducerDriven Marketing Channels in Australia”, British Food Journal, 113 (10): 1217-1228.

Burton, M., Rigby, D. and Young, T. (2003), "Modelling the adoption of organic horticultural technology in the UK using duration analysis", The Australian Journal of Agricultural and Resource Economics, 47: 1, 29-54.

Darby, N.R., and Karni, E. (1973), "Free competition and the optimal amount of fraud", Journal of law and economics, 16: 67-88.

Dörr, A.C., and Grote, U. (2009). "Impact of certification on fruit producers in the Sao Francisco Valley in Brazil", Economics and Applied Informatics, 2: 5-16.

Enjolras, G., and Sentis, P. (2011), "Crop insurance policies and purchases in France", Agricultural Economics, 42(4): 475-486.

Enjolras, G., Capitanio, F., Aubert, M., and Adinolfi, F. (2014), "Direct payments, crop insurance and the volatility of farm income. Some evidence in France and in Italy", New Medit, 13(1): 31-40.

Fernandez-Cornejo, J. (1996). "The microeconomic impact of IPM adoption: theory and application", Agricultural and Resources Economics Review, 25(2): 149-160.

Fernandez-Cornejo, J., and Ferraioli, J. (1999). "The environmental effects of adopting IPM techniques: The case of peach producers", Journal of Agricultural and Applied Economics, 31: 551-564.

Fernandez-Cornejo, J., Douglas Beach, E. and Wen-Yuan H. (1994), "The Adoption of IPM Techniques By Vegetable Growers in Florida, Michigan and Texas", Journal of Agricultural and Applied Economics, 26(1): 158-172.

Galt, R.E. (2008), "Toward an Integrated understanding of pesticide use Intensity in Costa Rican vegetable farming", Human Ecology, 36: 655-677.

Giraud-Héraud, E., Rouached, L. and Soler, L.G. (2006), "Private labels and public quality standards: How can consumer trust be restored after the mad cow crisis?", Quantitative Marketing and Economics, 4: 31-55.

Gonzalez-Diaz, M., and Raynaud, E. (2007), "La gouvernance de la qualité des produits", Economie Rurale, 299: 42-57.

Goodman, D., DuPuis, E.M. and Goodman, M.K. (2012), "Alternative food networks: knowledge, practice and politics", Routledge, Abingdon, Oxon, England, 320 p. 
Heckman, J. (2006), "A history of organic farming: Transitions from Sir Albert Howard's War in the Soil to USDA National Organic Program", Renewable Agriculture and Food Systems, 21(3): 143-150.

Ilbery, B . and Maye, D. (2005), "Alternative (shorter) food supply chains and specialist livestock products in the Scottish - English borders", Environment and Planning A, 37(5) : 823- 844.

Ilbery, B., Morris, C., Buller, H., Maye, D., and Kneafsey, M. (2005), "Product, Process and Place: An Examination of Food Marketing and Labelling Schemes in Europe and North America", European Urban and Regional Studies, 12(2): 116-132.

Kneafsey, M., Venn, L., Schmutz, U., Balázs, B., Trenchard, L., Eyden-Wood, T., Bos, E., Sutton, G., and Blackett, M. (2013), "Short Food Supply Chains and Local Food Systems in the EU. A State of Play of their Socio-Economic Characteristics", JRC Report 25911, 6/2013.

Kottila, M.R., and Rönni, P. (2008), "Collaboration and trust in two organic food chains", British Food Journal, 110 (4/5): 376-394.

McNamara, M.E.W., and Keith Douce, G. (1991), "Factors affecting peanut producer adoption of integrated pest management", Review of Agricultural Economics, 13: 129-139.

Maréchal, G., and Spanu, A. (2010), "Les circuits courts favorisent-ils l'adoption de pratiques agricoles plus respectueuses de l'environnement ?", Courrier de l'environnement de l'INRA, 59: $33-45$.

Moustier, P., and Nguyen, T.T.L. (2013), "Le circuit court, mode de certification sanitaire des legumes au Vietnam", INRA-SFER-CIRAD, Angers-France, December 2013, 12p.

Penker, M. (2006), "Mapping and measuring the ecological embeddedness of food supply chains", Geoforum, 37: 368-379.

Penrose, E.T. (1959), “The Theory of the Growth of the Firm”, New York: Wiley \& Sons, 272 p.

Prigent-Simonin, A.H., and Hérault-Fournier, C. (2005), "The role of trust in the perception of the quality of local food products: with particular reference to direct relationships between producer and consumer", Anthropology of food, May 2005.

Purdy, B.M., Langemeier, M.R., and Featherstone, A.M. (1997), "Financial Performance, Risk, And Specialization", Journal of Agricultural and Applied Economics, 29: 149-161.

Redlingshofer, B. (2008), “L'impact des circuits courts sur l'environnement", In Maréchal, G. (Ed.), Les circuits courts alimentaires, bien manger dans les territoires, Editions Educagri, Paris, 175-187.

Renting, H., Marsden, T., and Banks, J. (2003), "Understanding alternative food networks: exploring the role of short food supply chains in rural development", Environment and Planning A, 35: 393-411. 
Sylvander, B., and Schieb-Bienfait, N. (2006), "The strategic turn of Organic Farming in Europe : from a resource based to an entrepreneurial approach of Organic Marketing Initiatives", in Marsden, T., and Murdoch, J. (Eds), Between the local and the global, Confronting complexity in the contemporary food sector, Emerald Group Publishing Limited, 323-358.

Tuomisto, H.L., Hodge, I.D., Riordan, P., and Macdonald, D.W. (2012), "Does organic farming reduce environmental impacts? A meta-analysis of European research", Journal of environmental management, 112: 309-320.

Venn, L., Kneafsey, M., Holloway, L., Cox, R., Dowler, E., and Tuomainen, H. (2006), "Researching European "alternative" food networks: some methodological considerations", Area, 38(3): 248-258.

Vincq, J-L., Mondy, B., and Fontorbes, J. (2010), "La construction de la qualité fiable dans les réseaux alimentaires de proximité”, Economie Rurale, 318-319: 5-19.

Williamson, O.E. (1971), "The Vertical Integration of Production: Market Failure Considerations", American Economic Review, 61: 112-23.

Williamson, O.E. (1987), “The Economic Institutions of Capitalism”, New York: The Free Press, Collier Macmillan Publishers, 450p. 
Table 1a. List of main variables - Determinants of environment-friendly practices

\begin{tabular}{|c|c|c|c|c|}
\hline & Variable & Unit & Definition & $\begin{array}{l}\text { Expecte } \\
\text { influenc }\end{array}$ \\
\hline \multicolumn{5}{|c|}{ H1: Resources } \\
\hline \multicolumn{2}{|l|}{ Area } & Hectare & Cultivated area & + \\
\hline \multicolumn{2}{|c|}{ Employees / cultivated area } & - & Number of salaried employees per hectare & \multirow{3}{*}{+} \\
\hline \multicolumn{2}{|c|}{ \% permanent employees } & $\%$ & $\%$ of permanent salaried employees in total workforce & \\
\hline \multicolumn{2}{|c|}{ \% employees / total employment } & $\%$ & $\%$ of salaried employees in total workforce & \\
\hline \multicolumn{2}{|c|}{ Degree of specialization in wine-growing } & $\%$ & $\%$ of the standard gross output derived from wine-growing & \multirow{2}{*}{+} \\
\hline \multicolumn{2}{|c|}{ Degree of specialization in arboriculture } & $\%$ & $\%$ of the standard gross output derived from arboriculture & \\
\hline \multicolumn{5}{|c|}{ H2: Skills } \\
\hline \multirow{4}{*}{$\begin{array}{l}\text { Agricultural } \\
\text { education }\end{array}$} & No & - & The farmer has no agricultural education & \multirow{8}{*}{+} \\
\hline & Primary & - & The farmer has a primary level of agricultural education & \\
\hline & Secondary & - & The farmer has a secondary level of agricultural education & \\
\hline & Higher & - & The farmer has a higher level of agricultural education & \\
\hline \multirow{4}{*}{$\begin{array}{l}\text { General } \\
\text { education }\end{array}$} & No & - & The farmer has no general education & \\
\hline & Primary & - & The farmer has a primary level of general education & \\
\hline & Secondary & - & The farmer has a secondary level of general education & \\
\hline & Higher & - & The farmer has a higher level of general education & \\
\hline \multicolumn{2}{|l|}{ Age } & Year & Farmer's age & - \\
\hline \multirow{3}{*}{$\begin{array}{l}\text { Time worked } \\
\text { on farm }\end{array}$} & $<25 \%$ & - & The farmer spends less than $25 \%$ of his working time on the farm & \multirow{3}{*}{+} \\
\hline & $25 \%-50 \%$ & - & The farmer spends between $25 \%$ and $50 \%$ of his working time on the farm & \\
\hline & $50 \%-75 \%$ & - & The farmer spends between $50 \%$ and $75 \%$ of his working time on the farm & \\
\hline
\end{tabular}


Table 1b. List of main variables - Determinants of vertical integration

\begin{tabular}{|c|c|c|c|}
\hline Variable & Unit & Definition & $\begin{array}{l}\text { Expected } \\
\text { influence }\end{array}$ \\
\hline \multicolumn{4}{|c|}{ H4: Size effect } \\
\hline Area & Hectare & Cultivated area & + \\
\hline \multicolumn{4}{|c|}{ H5: Uncertainty } \\
\hline Degree of specialization in wine-growing & $\%$ & $\%$ of the standard gross output issued from wine-growing & \multirow{2}{*}{+} \\
\hline Degree of specialization in arboriculture & $\%$ & $\%$ of the standard gross output issued from arboriculture & \\
\hline Inter-diversification & Counter & Number of different productions & - \\
\hline Intra-diversification in wine-growing & Counter & Number of different productions within wine-growing & \multirow{2}{*}{-} \\
\hline Intra-diversification in arboriculture & Counter & Number of different productions within arboriculture & \\
\hline Multi-peril crop insurance & Yes/No & The farmer subscribes to a multi-peril crop insurance & - \\
\hline Participation in a mutual fund & Yes/No & The farmer is involved in a mutual fund devoted to covering sanitary or environmental risks & - \\
\hline \multicolumn{4}{|c|}{ H6: Specificity } \\
\hline Organic farming & Yes/No & The farm has adopted an organic farming label or is going to within 5 years & + \\
\hline
\end{tabular}


Table 2. Correspondence between quality declared to consumers implemented in practice by producers

\begin{tabular}{|l|c|c|c|c}
\cline { 2 - 4 } \multicolumn{1}{c|}{} & \multicolumn{3}{c}{ Organic Farming } & $\begin{array}{r}\text { Correlation } \\
\text { Chi2 tes }\end{array}$ \\
\cline { 2 - 4 } \multicolumn{1}{c|}{ No } & Yes & All farms & $* * *$ \\
\hline $\begin{array}{l}\text { Age of the sprayer of the area without } \\
\text { phytosanitary treatments }\end{array}$ & $11.13 \%$ & $16.59 \%$ & $11.72 \%$ & $* * * 6$ \\
\hline $\begin{array}{l}\% \text { of farms benefitting from } \\
\text { external control }\end{array}$ & $80.28 \%$ & $91.64 \%$ & $81.35 \%$ & $* * *$ \\
\hline $\begin{array}{l}\% \text { of farms whose sprayers are } \\
\text { controlled }\end{array}$ & $28.95 \%$ & $33.26 \%$ & $30.41 \%$ & $* * *$ \\
\hline
\end{tabular}

Key:

- Correlation tests: $\mathrm{H}_{0}=$ There is no difference between OF and non-OF. indicate that this hypothesis is accepted at the $1 \%, 5 \%$ and $10 \%$ levels respectiv - Chi2 tests: $* * *, * *$ and $*$ denote a significant relation at the $1 \%, 5 \%$ and 10 between being an $\mathrm{OF}$ and other qualitative variables. 
Table 3a. Individual characteristics of farmers specializing in wine-growing

\begin{tabular}{|c|c|c|c|c|c|c|c|c|c|c|}
\hline & \multicolumn{9}{|c|}{ Organic Farming } \\
\hline & & \multicolumn{3}{|c|}{ Population } & \multicolumn{3}{|c|}{ Percentage (line) } & \multicolumn{3}{|c|}{ Percentage (column) } \\
\hline & & No & Yes & $\begin{array}{c}\text { All } \\
\text { farms }\end{array}$ & No & Yes & $\begin{array}{c}\text { All } \\
\text { farms }\end{array}$ & No & Yes & All farms \\
\hline \multirow{4}{*}{$\begin{array}{l}\text { Agricultural } \\
\text { education }\end{array}$} & No & 26,766 & 1,777 & 28,543 & $93.77 \%$ & $6.23 \%$ & $100.00 \%$ & $48.76 \%$ & $33.64 \%$ & $47.43 \%$ \\
\hline & Primary & 15,321 & 1,209 & 16,530 & $92.69 \%$ & $7.31 \%$ & $100.00 \%$ & $27.91 \%$ & $22.88 \%$ & $27.47 \%$ \\
\hline & Secondary & 6,690 & 907 & 7,597 & $88.06 \%$ & $11.94 \%$ & $100.00 \%$ & $12.19 \%$ & $17.17 \%$ & $12.63 \%$ \\
\hline & Higher & 6,114 & 1,390 & 7,504 & $81.48 \%$ & $18.52 \%$ & $100.00 \%$ & $11.14 \%$ & $26.31 \%$ & $12.47 \%$ \\
\hline \multirow{4}{*}{$\begin{array}{l}\text { General } \\
\text { education }\end{array}$} & No & 4,604 & 241 & 4,845 & $95.03 \%$ & $4.97 \%$ & $100.00 \%$ & $8.39 \%$ & $4.56 \%$ & $8.05 \%$ \\
\hline & Primary & 24,827 & 1,318 & 26,145 & $94.96 \%$ & $5.04 \%$ & $100.00 \%$ & $45.23 \%$ & $24.95 \%$ & $43.45 \%$ \\
\hline & Secondary & 11,283 & 1,362 & 12,645 & $89.23 \%$ & $10.77 \%$ & $100.00 \%$ & $20.56 \%$ & $25.78 \%$ & $21.01 \%$ \\
\hline & Higher & 14,177 & 2,362 & 16,539 & $85.72 \%$ & $14.28 \%$ & $100.00 \%$ & $25.83 \%$ & $44.71 \%$ & $27.49 \%$ \\
\hline \multirow{4}{*}{$\begin{array}{l}\text { Time worked } \\
\text { on farm }\end{array}$} & $<25 \%$ & 21,885 & 995 & 22,880 & $95.65 \%$ & $4.35 \%$ & $100.00 \%$ & $39.87 \%$ & $18.83 \%$ & $38.02 \%$ \\
\hline & $25 \%-50 \%$ & 2,986 & 277 & 3,263 & $91.51 \%$ & $8.49 \%$ & $100.00 \%$ & $5.44 \%$ & $5.24 \%$ & $5.42 \%$ \\
\hline & $50 \%-75 \%$ & 1,788 & 186 & 1,974 & $90.58 \%$ & $9.42 \%$ & $100.00 \%$ & $3.26 \%$ & $3.52 \%$ & $3.28 \%$ \\
\hline & $>75 \%$ & 28,232 & 3,825 & 32,057 & $88.07 \%$ & $11.93 \%$ & $100.00 \%$ & $51.43 \%$ & $72.40 \%$ & $53,27 \%$ \\
\hline \multicolumn{2}{|l|}{ All farms } & 54,891 & 5,283 & 60,174 & $91.22 \%$ & $8.78 \%$ & $100.00 \%$ & $91.22 \%$ & $8.78 \%$ & $100.00 \%$ \\
\hline
\end{tabular}

Source: Agreste - Exhaustive census of French farms 2010

\begin{tabular}{|l|c|c|c|}
\hline \multirow{2}{*}{} & \multicolumn{3}{|c|}{ Organic Farming } \\
\cline { 2 - 4 } & No & Yes & All farms \\
\hline Age (average) & 51.68 & 47.19 & 51.29 \\
\hline
\end{tabular}

Source: Agreste - Exhaustive census of French farms (2010) 
Table 3b. Individual characteristics of farmers specializing in arboriculture

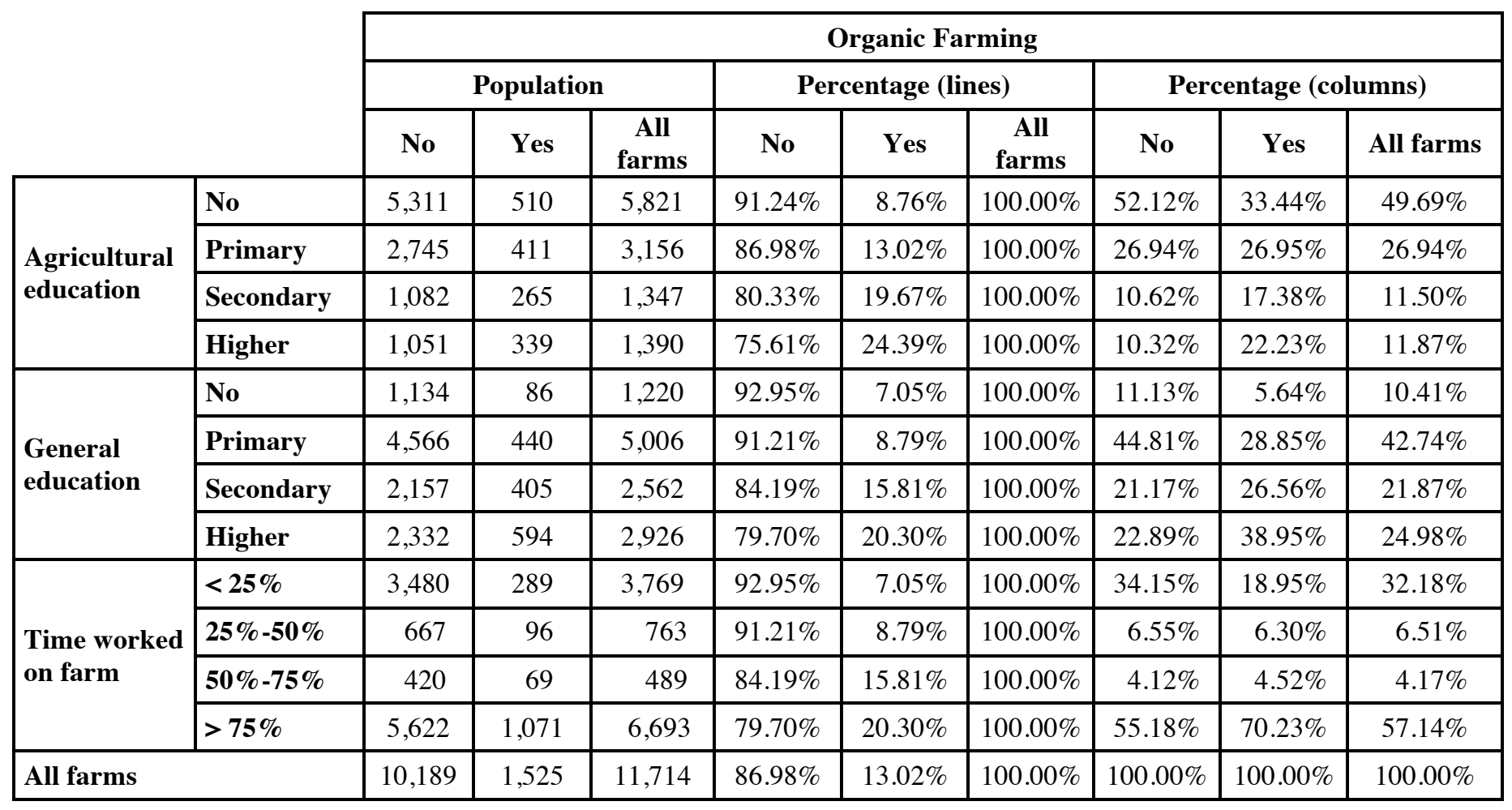

Source: Agreste - Exhaustive census of French farms 2010

\begin{tabular}{|l|c|c|c|}
\hline \multirow{2}{*}{} & \multicolumn{3}{|c|}{ Organic Farming } \\
\cline { 2 - 4 } & No & Yes & All farms \\
\hline Age (average) & 53.36 & 48.00 & 52.66 \\
\hline
\end{tabular}

Source: Agreste - Exhaustive census of French farms (2010) 
Table 4a. Structural characteristics of farms specializing in wine-growing

\begin{tabular}{|l|c|r|c|}
\cline { 2 - 4 } \multicolumn{1}{c|}{} & \multicolumn{3}{c|}{ Organic Farming } \\
\cline { 2 - 4 } \multicolumn{1}{c|}{} & \multicolumn{1}{c|}{ No } & \multicolumn{1}{c|}{ Yes } & All farms \\
\hline Cultivated area & 16.49 & 24.67 & 17.21 \\
\hline Employees / cultivated area & 0.41 & 0.24 & 0.39 \\
\hline \% permanent employees & 15.38 & 27.75 & 16.47 \\
\hline$\%$ employees / total employment & 0.13 & 0.23 & 0.13 \\
\hline Degree of specialization in wine-growing & 97.06 & 96.75 & 97.03 \\
\hline Degree of specialization in arboriculture & 0.65 & 1.19 & 0.70 \\
\hline Inter-diversification & 1.32 & 1.44 & 1.33 \\
\hline Intra-diversification in wine-growing & 1.25 & 1.40 & 1.27 \\
\hline Intra-diversification in arboriculture & 0.08 & 0.20 & 0.09 \\
\hline
\end{tabular}

Source: Agreste - Exhaustive census of French farms 2010

Table 4b. Structural characteristics of farms specializing in arboriculture

\begin{tabular}{|l|r|r|r|}
\cline { 2 - 4 } \multicolumn{1}{c|}{} & \multicolumn{3}{c|}{ Organic Farming } \\
\cline { 2 - 4 } \multicolumn{1}{c|}{} & No & Yes & All farms \\
\hline Cultivated area & 19.87 & 28.31 & 20.97 \\
\hline Employees / cultivated area & 0.30 & 0.21 & 0.29 \\
\hline \% permanent employees & 10.26 & 16.76 & 11.11 \\
\hline \% employees / total employment & 0.09 & 0.14 & 0.10 \\
\hline Degree of specialization in wine-growing & 7.16 & 9.24 & 7.43 \\
\hline Degree of specialization in arboriculture & 87.00 & 84.07 & 86.62 \\
\hline Inter-diversification & 1.76 & 1.95 & 1.79 \\
\hline Intra-diversification in wine-growing & 0.28 & 0.36 & 0.29 \\
\hline Intra-diversification in arboriculture & 1.81 & 2.22 & 1.86 \\
\hline
\end{tabular}

Source: Agreste - Exhaustive census of French farms 2010 
Table 5a. Adoption of OF label and integration on farms specializing in wine-growing

\begin{tabular}{|c|c|c|c|c|c|c|c|c|c|c|}
\hline & \multicolumn{9}{|c|}{ Organic Farming } \\
\hline & & \multicolumn{3}{|c|}{ Population } & \multicolumn{3}{|c|}{ Percentage (lines) } & \multicolumn{3}{|c|}{ Percentage (columns) } \\
\hline & & No & Yes & All & No & Yes & All & No & Yes & All \\
\hline \multirow{4}{*}{ Integration } & Integrated & 238 & 50 & 288 & $82.64 \%$ & $17.36 \%$ & $100.00 \%$ & $0.43 \%$ & $0.95 \%$ & $0.48 \%$ \\
\hline & Hybrid & 14,270 & 2,804 & 17,074 & $83.58 \%$ & $16.42 \%$ & $100.00 \%$ & $26.00 \%$ & $53.08 \%$ & $28.37 \%$ \\
\hline & Non-integrated & 40,383 & 2,429 & 42,812 & $94.33 \%$ & $5.67 \%$ & $100.00 \%$ & $73.57 \%$ & $45.98 \%$ & $71.15 \%$ \\
\hline & All & 54,891 & 5,283 & 60,174 & $91.22 \%$ & $8.78 \%$ & $100.00 \%$ & $100.00 \%$ & $100.00 \%$ & $100.00 \%$ \\
\hline
\end{tabular}

Source: Agreste - Exhaustive census of French farms 2010

Table 5b. Adoption of OF label and integration on farms specializing in arboriculture

\begin{tabular}{|c|c|c|c|c|c|c|c|c|c|c|}
\hline & \multicolumn{9}{|c|}{ Organic Farming } \\
\hline & & \multicolumn{3}{|c|}{ Population } & \multicolumn{3}{|c|}{ Percentage (lines) } & \multicolumn{3}{|c|}{ Percentage (columns) } \\
\hline & & No & Yes & All & No & Yes & All & No & Yes & All \\
\hline \multirow{4}{*}{ Integration } & Integrated & 1,878 & 365 & 2,243 & $83.73 \%$ & $16.27 \%$ & $100.00 \%$ & $18.43 \%$ & $23.93 \%$ & $19.15 \%$ \\
\hline & Hybrid & 1,596 & 415 & 2,011 & $79.36 \%$ & $20.64 \%$ & $100.00 \%$ & $15.66 \%$ & $27.21 \%$ & $17.17 \%$ \\
\hline & \begin{tabular}{|l|} 
Non-integrated \\
\end{tabular} & 6,715 & 745 & 7,460 & $90.01 \%$ & $9.99 \%$ & $100.00 \%$ & $65.90 \%$ & $48.85 \%$ & $63.68 \%$ \\
\hline & All & 10,189 & 1525 & 11,714 & $86.98 \%$ & $13.02 \%$ & $100.00 \%$ & $100.00 \%$ & $100.00 \%$ & $100.00 \%$ \\
\hline
\end{tabular}

Source: Agreste - Exhaustive census of French farms 2010 
Table 6a. Characteristics of farms specializing in wine-growing according to their degree of integration

\begin{tabular}{|l|c|c|c|c|}
\cline { 2 - 5 } \multicolumn{1}{c|}{} & \multicolumn{3}{c|}{ Integration } \\
\cline { 2 - 5 } \multicolumn{1}{c|}{} & Integrated & Hybrid & $\begin{array}{c}\text { Non- } \\
\text { integrated }\end{array}$ & $\begin{array}{c}\text { All } \\
\text { farms }\end{array}$ \\
\cline { 2 - 5 } Cultivated area & 27.28 & 23.35 & 14.69 & 17.21 \\
\hline Degree of specialization in wine-growing & 87.41 & 97.33 & 96.98 & 97.03 \\
\hline Degree of specialization in arboriculture & 5.79 & 0.65 & 0.69 & 0.70 \\
\hline Inter-diversification & 2.10 & 1.34 & 1.32 & 1.33 \\
\hline Intra-diversification in wine-growing & 1.74 & 1.31 & 1.25 & 1.27 \\
\hline Intra-diversification in arboriculture & 0.61 & 0.10 & 0.08 & 0.09 \\
\hline
\end{tabular}

\begin{tabular}{|l|c|c|c|c|c|}
\cline { 3 - 6 } \multicolumn{2}{c|}{} & \multicolumn{4}{c|}{ Integration } \\
\cline { 3 - 6 } \multicolumn{2}{c|}{} & Integrated & Hybrid & $\begin{array}{c}\text { Non- } \\
\text { integrated }\end{array}$ & $\begin{array}{c}\text { All } \\
\text { farms }\end{array}$ \\
\hline \multirow{2}{*}{ Multi-peril crop insurance } & Yes & $0.47 \%$ & $28.34 \%$ & $71.20 \%$ & $100.00 \%$ \\
\cline { 2 - 6 } & No & $0.55 \%$ & $28.58 \%$ & $70.87 \%$ & $100.00 \%$ \\
\hline \multirow{2}{*}{ Participation in a mutual fund } & Yes & $0.47 \%$ & $28.17 \%$ & $71.36 \%$ & $100.00 \%$ \\
\cline { 2 - 6 } & No & $0.93 \%$ & $36.89 \%$ & $62.18 \%$ & $100.00 \%$ \\
\hline All farms & & $0,48 \%$ & $29.37 \%$ & $71.15 \%$ & $100.00 \%$ \\
\hline
\end{tabular}

Source: Agreste - Exhaustive census of French farms 2010

Table 6b. Characteristics of farms specializing in arboriculture according to their degree of integration

\begin{tabular}{|l|c|c|c|c|}
\cline { 2 - 5 } \multicolumn{1}{c|}{} & \multicolumn{3}{c|}{ Integration } \\
\cline { 2 - 5 } \multicolumn{1}{c|}{} & Integrated & Hybrid & $\begin{array}{c}\text { Non- } \\
\text { integrated }\end{array}$ & All farms \\
\hline Cultivated area & 12.89 & 27.52 & 21.64 & 20.97 \\
\hline Degree of specialization in wine-growing & 3.60 & 10.58 & 7.72 & 7.43 \\
\hline Degree of specialization in arboriculture & 89.92 & 81.19 & 87.08 & 86.62 \\
\hline Inter-diversification & 1.72 & 2.15 & 1.71 & 1.79 \\
\hline Intra-diversification in wine-growing & 0.18 & 0.44 & 0.29 & 0.29 \\
\hline Intra-diversification in arboriculture & 2.34 & 2.45 & 1.56 & 1.86 \\
\hline
\end{tabular}

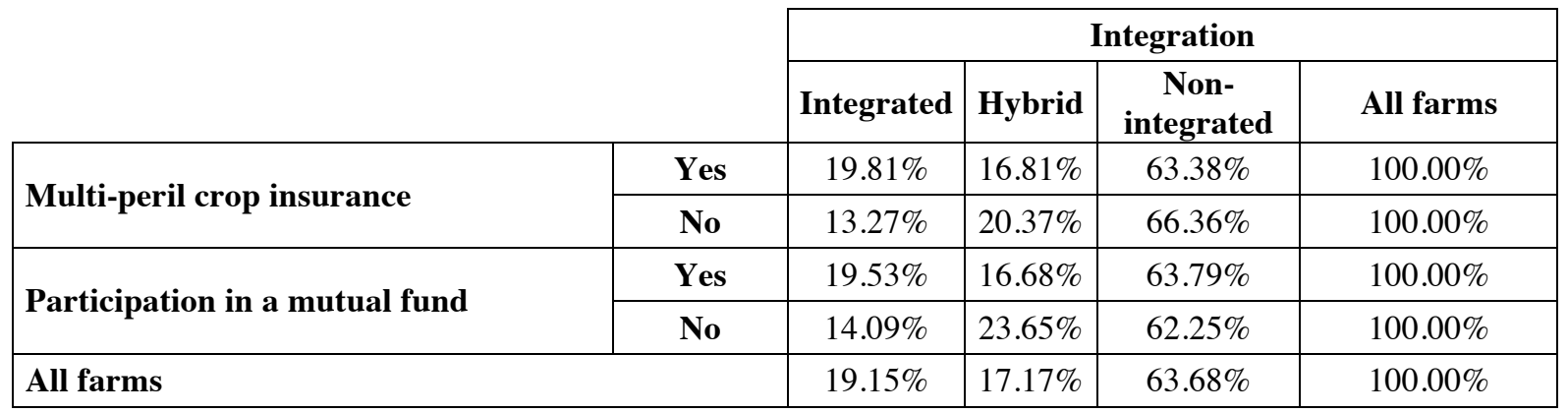

Source: Agreste - Exhaustive census of French farms 2010 
Table 7. Econometric models

\begin{tabular}{|c|c|c|c|}
\hline & & $\begin{array}{c}\text { Farms specializing in } \\
\text { wine-growing }\end{array}$ & $\begin{array}{l}\text { Farms specializing in } \\
\text { arboriculture }\end{array}$ \\
\hline \multicolumn{4}{|c|}{ Determinants of Organic Farming } \\
\hline \multicolumn{2}{|l|}{ Intercept } & $4.602 * * *$ & $2.456 * * *$ \\
\hline \multicolumn{2}{|l|}{ Integration } & $2.143 * * *$ & $1.152 * * *$ \\
\hline \multicolumn{2}{|c|}{ Cultivated area } & $-0.005^{* * *}$ & $0.002 * * *$ \\
\hline \multicolumn{2}{|c|}{ Employees / cultivated area } & $-0.182 * * *$ & $-0.111 * * *$ \\
\hline \multicolumn{2}{|c|}{ \% employees / total employment } & $0.041 * * *$ & $0.147 * * *$ \\
\hline \multicolumn{2}{|c|}{ Specialization in wine-growing } & 0.001 & \\
\hline \multicolumn{2}{|c|}{ Specialization in arboriculture } & & $-0.003 * * *$ \\
\hline \multirow{4}{*}{ Activity } & Farmer & \multicolumn{2}{|c|}{ Reference } \\
\hline & Farmer in another farm & -0.014 & 0.018 \\
\hline & Employee & $-0.106 * * *$ & 0.0005 \\
\hline & Retired & $-0.326^{* * *}$ & $-0.246^{* * *}$ \\
\hline \multirow{4}{*}{ Time on farm } & $<25 \%$ & \multicolumn{2}{|c|}{ Reference } \\
\hline & $25 \%-50 \%$ & $0.165 * * *$ & $0.176^{* * *}$ \\
\hline & $50 \%-75 \%$ & $0.181 * * *$ & $0.175^{* * *}$ \\
\hline & $>75 \%$ & $0.172 * * *$ & $0.146^{* * *}$ \\
\hline \multirow{4}{*}{ Agricultural education } & No & \multicolumn{2}{|c|}{ Reference } \\
\hline & Primary & 0.008 & $0.064 * * *$ \\
\hline & Secondary & 0.152 & $0.119 * * *$ \\
\hline & Higher & 0.017 & $0.134 * * *$ \\
\hline \multirow{4}{*}{ General education } & No & \multicolumn{2}{|c|}{ Reference } \\
\hline & Primary & 0.032 & 0.069 \\
\hline & Secondary & $0.215^{* * *}$ & $0.202 * * *$ \\
\hline & Higher & $0.226 * * *$ & $0.268 * * *$ \\
\hline \multicolumn{2}{|l|}{ Farmer's age } & $-0.001 * * *$ & $-0.004 * * *$ \\
\hline \multicolumn{2}{|l|}{ Inter-diversification } & 0.006 & $-0.104 * * *$ \\
\hline \multicolumn{2}{|c|}{ Intra-diversification in wine-growing } & $0.054 * * *$ & \\
\hline \multicolumn{2}{|c|}{ Intra-diversification in arboriculture } & & $-0.061 * * *$ \\
\hline \multicolumn{4}{|c|}{ Determinants of integration } \\
\hline \multicolumn{2}{|l|}{ Intercept } & $-2.881 * * *$ & $-1.720 * * *$ \\
\hline \multicolumn{2}{|l|}{ Organic farming } & $2.145^{* * *}$ & $1.536 * * *$ \\
\hline \multicolumn{2}{|c|}{ Cultivated area } & $0.005 * * *$ & $-0.004 * * *$ \\
\hline \multicolumn{2}{|c|}{ Specialization in wine-growing } & 0.001 & \\
\hline \multicolumn{2}{|c|}{ Specialization in arboriculture } & & $0.004 * * *$ \\
\hline \multicolumn{2}{|c|}{ Inter-diversification } & $-0.053 * * *$ & $0.138 * * *$ \\
\hline Intra-diversification in & -growing & 0.001 & \\
\hline Intra-diversification in a & riculture & & $0.096 * * *$ \\
\hline Multi-peril crop insuran & & $-0.021 * * *$ & $0.076^{* * *}$ \\
\hline Participation in a mutua & & 0.023 & $-0.105 * * *$ \\
\hline
\end{tabular}

Source: Agreste - Exhaustive census of French farms 2010

Keys: Estimates significant at the $10 \%(*), 5 \%(* *)$ and $1 \%(* *)$ thresholds. 